\title{
AUTONOMY AND BENEFICENCE IN ASSISTED DYING IN CANADA: The Eligibility OF MATURE MinORS
}

\author{
Juliet Guichon, FARAH MOHAMED, \\ KIM CLARKE, AND IAN MITCHELL*
}

\begin{abstract}
In Carter v. Canada (Attorney General), the Supreme Court of Canada legalized physicianassisted dying. Responding to this decision, Parliament passed Bill C-14, which provides that adults who suffer intolerably from a terminal medical condition may seek assistance to end their lives. Notably, the legislation does not grant access to mature minors. This article considers whether access should be granted, examining the Canadian assisted dying framework, situations of minors who might seek assisted dying, the law concerning mature minor consent to medical treatment, and other jurisdictions that grant access to mature minors. It argues that the ethical principles of autonomy and beneficence that underlie the Carter decision should be used to determine whether mature minors should have access to physician-assisted dying.
\end{abstract}

\section{TABLE OF CONTENTS}

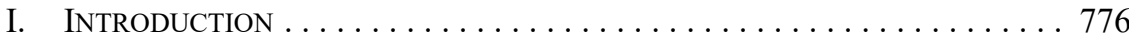

II. THE CARTER DeCiSION . . . . . . . . . . . . . . . . . . . . . . . . 777

III. Youth SeEking Assisted Dying $\ldots \ldots \ldots \ldots \ldots \ldots \ldots \ldots \ldots \ldots \ldots \ldots$

A. Numbers Likely to be SMall in CANADA $\ldots \ldots \ldots \ldots \ldots . \ldots 781$

B. Dutch and Belgian EXPERIENCE $\ldots \ldots \ldots \ldots \ldots \ldots \ldots \ldots . \ldots \ldots 2$

C. Medical Situation of Youth Who

Might REQUeSt AsSISTED DYING $\ldots \ldots \ldots \ldots \ldots \ldots \ldots \ldots . \ldots 78$

IV. MATURE MinORS AND CARTER . ................... 786

V. Mature Minors and Consent to Health Care in CANADA … . . 787

A. Overview . . . . . . . . . . . . . . . . . . . . 787

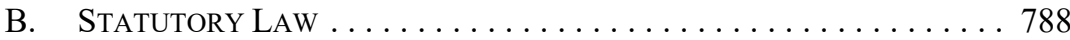

C. Common Law Mature Minor Doctrine . . . . . . . . . . . . . . . . 790

VI. MATURE Minors AND CHILd PROTECTION RELATED

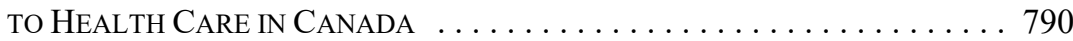

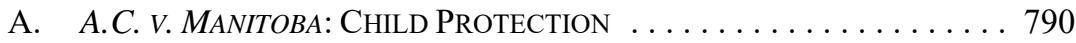

B. SumMARY ................................. 793

VII. MATURe Minor ACCeSS TO AsSisted Dying:

Legal, ETHICAL, AND Policy IsSUES . . . . . . . . . . . . . . . . . 793

A. LEgAL ARgUMENT For MATURE MinOR

ELIGIBILITY to ACCESS ASSISTED DYING . . . . . . . . . . 793

B. Legal ARgument for Mature Minor

ELIGIBILITY TO ACCESS AsSISTED DYING

BASED ON CHILD PROTECTION LAW

Juliet Guichon, BA, BA (Hon Juris), BCL, MA, SJD was called to the Bar of Ontario, and is Assistant Professor, Cumming School of Medicine, University of Calgary. Farah Mohamed, BHSc, JD, is a lawyer practicing in advanced care planning and health law in Calgary, Alberta. Kim Clarke, LLB, MLIS is head, Bennett Jones Law Library and Adjunct Associate Professor of Law, University of Calgary. Ian Mitchell, MB, MA, FRCPC, FCCP, MRCP (UK) is a Clinical Professor of Pediatrices, Cumming School of Medicine, University of Calgary. The authors thank the anonymous reviewer for very helpful comments. 


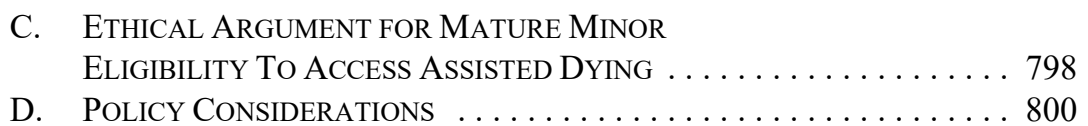

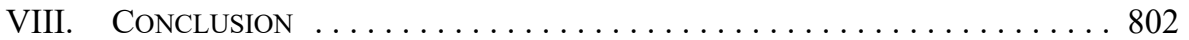

\section{INTRODUCTION}

The Supreme Court of Canada's unanimous decision in Carter v. Canada (Attorney General) ${ }^{1}$ transformed euthanasia and assisted suicide from criminal acts to health services. This transformation occurred because the Supreme Court focused on individuals and their desire to escape intolerable suffering caused by grievous and irremediable illness. Indeed, in the very first paragraph of the judgment, the Supreme Court decried the effect of the impugned Criminal Code of Canada provisions ${ }^{2}$ that prohibited assisted dying. The Supreme Court wrote:

people who are grievously and irremediably ill cannot seek a physician's assistance in dying and may be condemned to a life of severe and intolerable suffering. A person facing this prospect has two options: she can take her own life prematurely, often by violent or dangerous means, or she can suffer until she dies from natural causes. The choice is cruel. ${ }^{3}$

Promoting the ethical principles of autonomy and beneficence (acting with the best interests of the person in mind), the Carter decision effectively recognizes that Canadian law must respect the autonomous choice of competent adults to relieve intolerable suffering by seeking assistance in dying and that such a choice can be beneficent. The Carter decision has profound significance for end-of-life care for many Canadians including grievously and irremediably ill youth who seek aid in dying.

Neither the Carter decision nor Parliament's legislative response to it explicitly grants access to assisted dying to minors who are sufficiently mature to understand and appreciate the practice, and to request access for themselves. But Bill C-14, An Act to amend the Criminal Code and to make related amendments to other Acts (medical assistance in dying), ${ }^{4}$ foresees the possibility that youth might one day have access by requiring that the issue be studied. Clause 9.1(1) provides in part:

The Minister of Justice and the Minister of Health must, no later than 180 days after the day on which this Act receives royal assent, initiate one or more independent reviews of issues relating to requests by mature minors for medical assistance in dying.

Given that the legislation received royal assent on 17 June 2016, such review was required to begin by 14 December 2016. On 13 December 2016, the federal government announced that it had engaged the Council of Canadian Academies to conduct independent reviews to determine if assisted dying should be expanded to include mature minors, to people with

2015 SCC 5, [2015] 1 SCR 331 [Carter].

Criminal Code of Canada, RSC 1985, c C-46, ss 14, 241(b) as it appeared on 6 February 2015 [Criminal Code].

Carter, supra note 1 at para 1.

1st Sess, 42nd Parl, 2016 [Bill C-14]. 
competence eroding conditions who want to make advance requests, and to people suffering strictly from mental illnesses; and to report by December $2018 .{ }^{5}$

This article aims to contribute to consideration of the issue of whether mature minors have or ought to have access to medical assistance in dying by examining:

1. the assisted dying framework developed in Canada;

2. the types of medical situations of minors who might seek assisted dying;

3. the law in Canada as it relates to mature minor consent to medical treatment; and

4. the assisted dying framework in jurisdictions that grant eligibility to people under the age of majority.

This article argues that those who determine whether minors should have access to medical assistance in dying should be guided by the ethical principles of autonomy and beneficence, which underlie not only the Carter decision, but also the statutory and common law governing health care decision-making of minors, including the Supreme Court of Canada's decision in A.C. v. Manitoba (Director of Child and Family Services). ${ }^{6}$ A regime that grants assisted dying to mature minors might learn from the example of the Netherlands and Belgium, which permit the practice under strict conditions. Although very few minors are likely to request assistance in dying, to those few, the matter will be of central importance.

\section{THE CARTER DECISION ${ }^{7}$}

Although the decision of the Supreme Court of Canada that led to legislation about assisted dying did not concern minors, it is important to describe the case because it articulates the values that justify the practice. In the Carter decision, rendered in February 2015, the Supreme Court unanimously declared that the provisions ${ }^{8}$ of the Criminal Code that prohibit assisted suicide and assisted death are unconstitutional because they violate section 7 of the Charter and cannot be saved by section 1. The Supreme Court declared that the Criminal Code provisions are of no force and effect insofar as they prohibit assisted death for competent adults who are suffering intolerably from a grievous and irremediable medical condition and for whom there is no acceptable treatment. ${ }^{9}$

This case provided the Supreme Court with the opportunity to revisit the issue of assisted dying. In the 1993 decision Rodriguez v. British Columbia (Attorney General), ${ }^{10}$ a majority of the Supreme Court held that section 241(b) of the Criminal Code, which criminalized assisted suicide, did not violate section 7 of the Charter. The Supreme Court ruled further

Canadian Press, "Government Launches Promised Review of Issues Left Out of Assisted Dying Law: Review Will Consider Cases Involving Advanced Directives, Mental Illnesses and Mature Minors," CBC News (13 December 2016), online: <www.cbc.ca/news/politics/assisted-dying-review-1.389 $5421>$.

2009 SCC 30, [2009] 2 SCR 181 [AC v Manitoba].

Although this article does not address An Act respecting end-of-life care, RSQ c S-32.0001, it is important to note that that legislation does not permit physician-assisted dying for mature minors.

Criminal Code, supra note 2.

Supra note 1 at paras $123,127,147$.

[1993] 3 SCR 519 [Rodriguez]. 
that even if section 241(b) were discriminatory, and therefore in violation of section 15 of the Charter, then such violation was saved by section 1 of the Charter. ${ }^{11}$

Even though some of the adjudicative facts in Rodriguez were similar to those in Carter, ${ }^{12}$ the Supreme Court held that the doctrine of "stare decisis is not a straitjacket that condemns the law to stasis."13 The Supreme Court stated that settled rulings of higher courts may be reconsidered by lower courts "in two situations: (1) where a new legal issue is raised; and (2) where there is a change in the circumstances or evidence that 'fundamentally shifts the parameters of the debate." $" 14$

The Supreme Court held that both these conditions were met in Carter. First, the Supreme Court in Rodriguez did not consider whether the prohibition against assisted dying was grossly disproportionate and applied the overbreadth principle as it was then defined, not as it is now defined. ${ }^{15}$ Second, the legislative and social facts surrounding the acceptance of assisted dying before the Supreme Court in Carter are significantly different from those in Rodriguez. Whereas in 1993, when Rodriguez was decided, no western democracy expressly permitted assistance in dying, by 2010 "eight jurisdictions permitted some form of assisted dying: the Netherlands, Belgium, Luxembourg, Switzerland, Oregon, Washington, Montana, and Colombia." ${ }^{\prime 6}$ Analysis of these regimes created a body of evidence about the practical and legal aspects of assisted dying and the efficacy of safeguards for the vulnerable that addressed the majority's concerns in Rodriguez.

When asked to apply the Rodriguez decision, the Carter Court entirely rejected the earlier Supreme Court's ratio that was based on the sanctity of life, the "slippery slope,"17 and protecting the vulnerable.

Regarding the sanctity of life concern, the Supreme Court of Canada in Carter did not agree that the right to life "requires an absolute prohibition on assistance in dying, or that individuals cannot 'waive' their right to life."18 The Carter Court said that such an interpretation "would create a 'duty to live', rather than a right to life." ${ }^{, 19}$ Moreover, such an interpretation "would call into question the legality of any consent to the withdrawal or refusal of life-saving or life-sustaining treatment." 20 The Court found that, rather than prohibiting assistance in dying by protecting life at all costs, section 7 "encompasses life,

\footnotetext{
Ibid at 615 .

Sue Rodriguez and one of the Carter plaintiffs, Gloria Taylor, both had amyotrophic lateral sclerosis, a debilitating motor neuron disease that can lead to death by aspiration.

Carter, supra note 1 at para 44.

Ibid, citing Canada (Attorney General) v Bedford, 2013 SCC 72, [2013] 3 SCR 1101 at para 42.

Ibid at para 46.

Ibid at para 8. Vermont made the practice lawful in 2013, and California in 2015: US, Act 39, Bill S77, An Act Relating to Patient Choice and Control at End of Life, 2013 Reg Sess, Vt, 2013 (enacted); US, Bill S128, End of Life Option Act, 2015-2016, Reg Sess, Cal, 2015 (enacted).

17 The "slippery slope" argument is that once a particular change is made, other undesired changes will inevitably occur. The argument is both causal and evaluative. In the case of assisted dying, it holds that permitting the practice for some will inevitably lead to the killing of non-consenting persons and that this outcome would be bad. No party disputed that the feared outcome would be bad. Carter, supra note 1 at para 63 [emphasis in original].

Ibid.

Ibid.
} 
liberty and security of the person during the passage to death." ${ }^{21}$ In "certain circumstances, an individual's choice about the end of her life is entitled to respect.",22

The Supreme Court found that the other two section 7 rights — liberty and security of the person - were violated by the Criminal Code provisions because the provisions prevented the exercise of a fundamental personal choice and interfered with decision-making about bodily integrity. The Supreme Court affirmed that liberty protects "the right to make fundamental personal choices free from state interference," and security of the person "encompasses 'a notion of personal autonomy involving ... control over one's bodily integrity free from state interference"" and "is engaged by state interference with an individual's physical or psychological integrity, including any state action that causes physical or serious psychological suffering., 23

The Supreme Court noted that underlying both liberty and security of the person is a concern for the protection of an individual's autonomy and dignity. The Supreme Court stated that it was a violation of autonomy and dignity to permit some choices about end of life but not assistance in dying:

\footnotetext{
An individual's response to a grievous and irremediable medical condition is a matter critical to their dignity and autonomy. The law allows people in this situation to request palliative sedation, refuse artificial nutrition and hydration, or request the removal of life-sustaining medical equipment, but denies them the right to request a physician's assistance in dying. ${ }^{24}$
}

The assumption in the Supreme Court's argument is that, like palliative sedation and refusal of hydration, nutrition, and life-sustaining treatment, assistance in dying can be a beneficent form of health care.

Concern for the slippery slope argument and protecting the vulnerable was addressed by the Carter Court in its section 1 analysis. In assessing whether the Criminal Code provisions minimally impaired section 7, the Supreme Court noted that the trial judge found that an absolute prohibition on assistance in dying would have been necessary if the evidence demonstrated that

\footnotetext{
physicians were unable to reliably assess competence, voluntariness, and non-ambivalence in patients; that physicians fail to understand or apply the informed consent requirement for medical treatment; or if the evidence from permissive jurisdictions showed abuse of patients, carelessness, callousness, or a slippery slope, leading to the casual termination of life. ${ }^{25}$
}

But the trial judge expressly rejected these possibilities. In fact, the evidence led the trial judge to conclude that

Ibid.

Ibid.

Ibid at para 64, citing Rodriguez, supra note 10 at 587-88, Sopinka J, referring to $R v$ Morgentaler, [1988] 1 SCR 30.

Carter, ibid at para 66.

Ibid at para 104. 
the risks inherent in permitting physician-assisted death can be identified and very substantially minimized through a carefully-designed system imposing stringent limits that are scrupulously monitored and enforced. ${ }^{26}$

The Supreme Court agreed with the trial judge's conclusion. In other words, the feared result that "Canada will descend the slippery slope into euthanasia and condoned murder" was not credible. ${ }^{27}$ Rejecting this argument, the Supreme Court said, "[w]e should not lightly assume that the regulatory regime will function defectively, nor should we assume that other criminal sanctions against the taking of lives will prove impotent against abuse."28

The Supreme Court held that the violations of section 7 were not in accordance with the principles of fundamental justice ${ }^{29}$ or saved by section $1 .^{30}$ It did not reach the issue of whether the impugned sections violate section $15 .^{31}$

The legal effect of the Carter ruling is that a physician may assist a person to die without criminal sanction under sections 14 and 241(b) of the Criminal Code provided that the person is a competent adult who:

(a) clearly consents to the termination of life; and

(b) has a grievous and irremediable medical condition ... that causes enduring suffering that is intolerable to the individual in the circumstances of his or her condition. ${ }^{32}$

For such persons, a physician may directly administer medication to hasten death (euthanasia), or may provide a prescription for a lethal dose of medication for the patient to self-administer (assisted suicide). ${ }^{33}$

The Supreme Court of Canada suspended its declaration of invalidity for 12 months, until 6 February $2016,{ }^{34}$ and then for another four months to 6 June $2016^{35}$ to offer Parliament and the provincial and territorial legislatures time to respond, ${ }^{36}$ if they so chose, by enacting legislation consistent with the constitutional parameters that the Supreme Court set out in its

Ibid at para 105, citing Carter v Canada (AG), 2012 BCSC 886, 2012 BCSC 886 (CanLII) at para 883 [Carter Trial].

Carter, ibid at para 120.

Ibid.

Ibid at paras 71-92.

Ibid at para 123 .

Ibid at para 93.

Ibid at para 127.

Jocelyn Downie, "The Supreme Court of Canada Decision Allows for the Prescription and the Syringe" (1 March 2015), Impact Ethics (blog), online: <https://impactethics.ca/2015/03/01/the-supreme-courtof-canada-decision-allows-for-the-prescription-and-the-syringe/>.

Carter, supra note 1 at para 147.

Carter v Canada (Attorney General), 2016 SCC 4, [2016] 1 SCR 13 at para 2 [Carter Extension]. The extension did not apply to Quebec, where the Supreme Court's judgment had full effect on 6 February 2016. In June 2015, Quebec passed legislation which, inter alia, permits medical assistance in dying by physician-administered lethal injection only to consenting adults who are at the end of life (supra note 7).

Under section 91(27) of the Constitution Act, 1867 (UK), 30 \& 31 Vict, c 3, reprinted in RSC 1985 , Appendix II, No 5, issues of criminal law fall within the legislative competence of Parliament. Such federal jurisdiction includes any amendment to the Criminal Code regarding physician-assisted dying. Issues relating to hospitals, provision of medical services, civil rights, property, and matters of a merely local or private nature, including permissive legislation concerning physician-assisted dying, are within provincial jurisdiction: ibid, ss 92(7), 92(13), 92(16). 
reasons. ${ }^{37}$ During the four month extension period, the majority granted an exemption to individuals who wished to exercise their rights by applying to the superior court of their jurisdiction for relief in accordance with the Carter criteria. ${ }^{38}$

On 17 June 2016, the Governor General gave royal assent to Parliament's response to the Carter decision: Bill C-14, An Act to amend the Criminal Code and to make related amendments to other Acts (medical assistance in dying). ${ }^{39}$ The Act, however, is not consistent with the Supreme Court's constitutional parameters because the Act narrows the group of adults who may access medical assistance in dying to those whose death is "reasonably foreseeable." That fact was recognized by the unanimous decision of the Alberta Court of Appeal in Canada (Attorney General) v. E.F., ${ }^{40}$ when it held that Carter did not limit the right to assisted death to people "who are terminally ill or near the end of life." "41 The Court of Appeal reiterated that the justification for the constitutional right to assisted dying is the alleviation of suffering, when it stated: "The cruelty in the situation is there regardless of whether the illness causing the suffering may be classified as terminal." ${ }^{42}$

Whether the Act is constitutional in requiring that the individual have an incurable illness, be in an advanced state of irreversible decline, and whose death is reasonably foreseeable, is now under constitutional challenge by litigation launched in British Columbia in late June $2016 .^{43}$

\section{Youth Seeking Assisted DyING}

\section{A. Numbers Likely to Be SMall in CANADA}

Access to assisted dying is likely to be sought by only a very small number of minors. It is possible to make this prediction using data from Statistics Canada about deaths of people in Canada under the age of $18^{44}$ (accepting that there are limitations to these calculations). In 2012, there were 818 deaths of youth aged 15 to 19, but 365 youths (44.60 percent) died of external causes, mainly transport accidents and assault. There were also 227 minors who died of suicide. While the individual circumstances concerning each of these suicide deaths is not known, in general, suicide in teenagers is impulsive and opportunistic. It is unlikely that these deaths by suicide were a response to irremediable suffering as described in Carter. Therefore, the approximate number of people in Canada aged 15 to 19 who died of natural causes in 2012 was 216 . Assuming that people in this age group will request assisted dying

Carter, supra note 1 at 126.

Carter Extension, supra note 35 at para 6. See also Carter, supra note 1 at para 127.

Supra note 4.

2016 ABCA 155, 2016 ABCA 155 (CanLII) [EF].

Ibid at paras 32-33.

Ibid at para 37.

Lamb v Canada (AG), filed 27 June 2016, BCSC.

Statistics Canada, "Leading Causes of Death, Total Population, by Age Group and Sex, Canada," Table 102-0561, online: <www5.statcan. gc.ca/cansim/a47\#F21>. 
at a similar rate to adults in other jurisdictions - a rate between 0.02 and 3.90 percent $^{45}$ then it seems that, at most, eight youth might request assisted dying in the entire nation of Canada in any given year. ${ }^{46}$

\section{B. DUTCH AND BELGIAN EXPERIENCE}

The contention that few youth will seek access to assisted dying is supported by the experience in the two countries that allow minors to request assisted dying — the Netherlands ${ }^{47}$ and Belgium. ${ }^{48}$ In the Netherlands, less than 1.6 percent of all deaths of minors under the age of 16 are as the result of physician-assisted dying. ${ }^{49}$ Since access to euthanasia in Belgium was extended to children in February $2014,{ }^{50}$ only one case of euthanasia of a minor has occurred. ${ }^{51}$ That very few teens will access assisted dying underscores the fact that their situation is exceptional.

\section{Medical Situation OF Youth Who Might ReQuest ASSiSTed Dying}

The need for the provision of an exceptional response is not obvious. The very idea of assisted dying for people who are not adults is difficult to contemplate. ${ }^{52}$ Most people seek to help children thrive so that they can have long, healthy lives; when thinking about assisted dying for minors, it is difficult to contemplate a situation that would cause a minor to wish

A recent literature review concluded that " $[t]$ he percentage of physician-assisted deaths among all deaths ranged from $0.1 \%-0.2 \%$ in the US states and Luxembourg to $1.8 \%-2.9 \%$ in the Netherlands. Percentages of cases reported to the authorities increased in most countries over time. The typical person who died with assistance was a well-educated male cancer patient, aged 60-85 years." Nicole Steck et al, "Euthanasia and Assisted Suicide in Selected European Countries and US States: Systematic Literature Review" (2013) 51:10 Medical Care 938 at 938.

46 Some minors aged less than 15 years may be considered mature minors, but the mortality rate in this group is much smaller than the older teens we use as an example.

47 Act of April 12,2001: Review Procedures of Termination of Life on Request and Assisted Suicide and Amendment to the Penal Code and the Burial and Cremation Act (The Termination of Life on Request and Assistance With Suicide [Review Procedures] Act) at ch, 2 art 3, cls 3-4. Staatsblad 2001;1-8 online: <wetten.overheid.nl/BWBR0012410/2002-04-01> (Wet toetsing levensbeindiging op verzoek en hulp bij zelfdoding). Euthanasia Law, Actes parlementaires du Sénat de Belgique 2001-2002, Bruxelles, 2002; number $2-244 / 26$

Margaret P Battin et al, "Legal Physician-Assisted Dying in Oregon and the Netherlands: Evidence Concerning the Impact on Patients in 'Vulnerable' Groups" (2007) 33:10 J Medical Ethics 591 at 595. Belgian House of Representatives voted 86-44 (with 12 abstentions), following approval of the Belgian Senate in December 2013, see Associated Press in Brussels, "Belgium Passes Law Extending Euthanasia to Children of All Ages," The Guardian (13 February 2014), online: <www.theguardian.com/world/ 2014/feb/13/belgium-law-extends-euthanasia-children-all-ages>. This amendment had broad public support with 75 percent of responders to a Francophone Belgian Radio and Television (RTBF) poll stating that they favoured the extension to children. Charlotte McDonald-Gibson, "Belgium Extends Euthanasia Law to Kids," Time (13 February 2014), online: < time.com/7565/belgium-euthanasia-lawchildren-assisted-suicide/>. Chandrika Narayn, "First Child Dies by Euthanasia in Belgium," CNN (17 September 2016), online: <www.cnn.com/2016/09/17/health/belgium-minor-euthanaisa/>.

51 Dr. Wim Distelmans, palliative physician at the University Hospital, Brussels, and Chair of the the oversight office, the Federal Control and Evaluation Commission (FCEC), "Drie Meningen, Euthanasie Bij Minderjarigen" [Three Opinions, Euthanasia for Minors], de Standaard (18 May 2016), online: $<$ www.standaard.be $>$.

52 Regarding the possibility of assisted dying for minors, a paediatrican reported, "[o]ne of my residents kind of cringed and clutched her stomach.... That is the reaction": Tom Blackwell, "Doctors Roiled by Report Advising Assisted-Death Be Available to Mature Children and the Mentally Ill," National Post (25 February 2016), online: $<$ news.nationalpost.com/health/doctors-roiled-by-report-advising-assisteddeath-be-available-to-mature-children-and-the-mentally-ill?_lsa $=\mathrm{fb} 0 \mathrm{e}-\mathrm{a} 67 \mathrm{c}>$. 
for assistance in dying. The issue is not abstract for such minors. It is important, therefore, to examine the issue from the perspective of these youths.

Consider the following three cases of youth who might seek assisted dying. Although these cases are hypothetical, they are derived from one author's 45 years of paediatric medical practice. ${ }^{53}$

\section{LIAM'S STORY}

When Liam was a baby, his parents noticed that he was late to start walking. When he was about three years old, they noticed him falling frequently. After worrying for some weeks, they saw their family physician, and then a specialist who diagnosed Liam with Duchenne muscular dystrophy.

Liam does not remember being diagnosed and accepts that muscular dystrophy affects all aspects of his life. Now aged 16, Liam has been using a wheelchair for six years. He remembers being admitted to hospital twice: at age 12 for pneumonia and at age 14 for surgery for scoliosis. These experiences are only half-remembered because he was sedated, but all the memories are difficult, such as having a tube in his throat making it impossible to speak, being suctioned down the same tube to clear secretions, and the discomfort of being turned in bed frequently. During and after his second hospital admission, he had nightmares about that experience and nightmares about his previous experience in the intensive care unit.

After the scoliosis surgery, he began to need what the doctors called "non-invasive ventilation" at night to help him breathe. Initially he could set up the ventilator, and place the mask tightly around his nose and mouth. Recently, Liam has become weaker. He has trouble swallowing and chewing so the doctors conducted surgery to place a gastrostomy tube to allow food to go directly into his stomach. Because he cannot cough effectively, a machine helps clear secretions from his lungs so that he is less likely to contract pneumonia. He sometimes has painful muscle cramps that come unpredictably; none of the doctors have found a good way to help this discomfort. Liam sees a cardiologist from time to time and knows that his heart is not strong. His parents used to come into his room at night to turn him over so that he would not get bedsores. Now, health care aides are in his home every night to do that job.

Liam knows that his parents love him, and his nineteen year old sister, Olivia, is always kind and helpful. He has made friends with other boys with muscular dystrophy whom he meets at the clinic and he has friends at school.

Liam has noticed lately at the clinic that the physicians and his parents are having private discussions. He knows he is getting more tired, in a general sense, but also feels breathless quite often every day. He asked what was going on, and his parents explained that he may need to use the breathing machine all day and not just at night. They explained that he would have a mask strapped tightly to his face that he could remove when he wanted to speak or 
eat. Liam's parents also explained that members of the clinic staff have suggested that he have a tracheostomy tube - an artificial breathing tube in the throat.

Liam is aware of all of these medical devices; he has seen friends who have depended on them to keep them alive and has spoken to them about what life is like being dependent on those devices.

Liam sees all of these "helps" as a way of continuing his suffering and extreme discomfort. He believes that since he has needed a wheelchair, he has had a steady decline in what he is able to do and a very marked increase in the amount of discomfort and suffering.

Liam assures his family that, despite the dystrophy, he has enjoyed life overall, but he is suffering a great deal from the challenges of breathing, and the lack of pleasure in using his own body to move, to eat, and even to cough. He does not want to go to the next step of needing a permanent tube to help him breathe. He tells his family that he does not want more medical intervention to continue his life. He wants help in dying.

\section{EMILY'S STORY}

Emily is fifteen years of age. Her parents call her a miracle child, explaining that when she was diagnosed with spinal muscular atrophy at just over one year of age, everyone thought she would die within four or five years. She has never been able to stand or walk by herself, and is in a powered wheelchair. She uses a brace to hold herself upright.

Emily used to hope that a new treatment would be developed that would cure her and that she would be able to walk. But she now realizes that this dream will not come true. Emily feels imprisoned in the wheelchair rather than liberated by using it to get around.

Since she was four, Emily has used a tracheostomy tube to help her breathe. She has had difficulty swallowing, and has a gastrostomy tube so that she can be fed. She attends school every day when she is not sick, and has a health care aide. She has friends in school.

Emily remembers major surgery for her scoliosis, and being in an intensive care unit for weeks after the surgery. She was sedated, so her memories are vague, but they are all unpleasant and she has nightmares about that experience. She has clear memories when the sedation and pain relief were reduced, and with a period of continuing pain in the "recovery" phase of the intensive care unit admission.

Emily has had several admissions to hospital because of severe respiratory infections. Although she felt the staff were very kind, she feared each time that she was going to die, or perhaps drown in her own secretions. She is now very frightened every time she meets someone with a cold in case she must be re-admitted to hospital.

Her parents and aides help her with her breathing and the tracheostomy tube. They cut her food into small pieces so that she can have some food by mouth (though the gastrostomy 
tube is her main source of nutrition). Emily needs help with almost every activity such as bathing, toileting, and dressing.

Despite the spinal muscular atrophy, Emily saw herself as an independent person who needed some medical devices to live. But over the last two to three years, as she became weaker and more dependent on others, she has been thinking about her own death. Emily is able to use a computer and is well-informed about her prognosis. Ever since she read about assisted dying in a newspaper, Emily has been thinking about it. She raised the subject with a teacher, because she knew her parents had spent so much time caring for her that they might not be willing to let her go.

The teacher encouraged Emily to speak to her parents, whose first thought was that she might be depressed. Emily was then seen by a psychologist who is a member of the clinic team that cares for children with spinal muscular atrophy. The psychologist did not think Emily was depressed and thought that she was competent to make medical decisions.

\section{HIMMAT'S STORY}

Himmat is sixteen years old and has just been listening to his oncologist explain the plan to treat his leukemia. Himmat is familiar with the oncologist, the oncology unit, chemotherapy, and radiotherapy.

Himmat began developing this familiarity when he was seven. His eye hurt and was swollen, so his parents took him to his family doctor, and then to a children's hospital emergency department. Initially, the doctors thought he had an infection and started him on intravenous antibiotics. But when there was no change after a week, the doctors investigated further, including by ordering an MRI. This imaging test showed a mass in the left orbit pushing the eye off to one side. A biopsy showed that this was an embryonal rhabdomyosarcoma. Further tests showed no other tumors. Himmat was given chemotherapy and radiotherapy.

Himmat remembers this period of his life with horror. He had frequent hospital visits, and long admissions in the hospital. He remembers losing his hair after radiotherapy, and believing his whole body was going to disintegrate. During chemotherapy he had to avoid anyone who might have the slightest infection, but even so, he had several severe infections and was in hospital for treatment. Twice, he was in the intensive care unit and had major difficulty breathing, and still has difficult memories of those periods. The chemotherapy had many painful side effects. The worst of these was painful ulcers in his mouth that made it difficult to eat or speak. Doctors followed Himmat closely. Fortunately, two years after the first presentation (when he was age nine), he had no evidence of cancer.

At age 12, Himmat was having a shower when he felt a lump in his neck. An oncologist saw him urgently and conducted a biopsy, which confirmed a recurrence of rhabdomyosarcoma. Again Himmat had chemotherapy and radiotherapy, and again he responded to the treatment. His experience during this second course of cancer treatment was even more unpleasant than the first. He receives support from his parents, friends, and clinic staff to deal with recurring nightmares related to the previous two courses of treatment. 
During and between Himmat's courses of chemotherapy he was an active "poster child" for the oncologist service and his parents did a great deal of fundraising.

Once the treatment was completed, Himmat increased his activities and took part in sports. In the last several weeks, however, Himmat had been feeling weak and his parents thought he looked pale. He had urgent blood work, then bone marrow tests, that confirmed leukemia.

The oncologist and his parents believe there is no question that he will again have chemotherapy for leukemia. The oncologist has raised the issue of stem cell transplantation.

This time, Himmat has different ideas. Although he had enjoyed life before this third cancer came, he does not think that he can tolerate the inevitable side effects again. Himmat told his parents and oncologist that he does not wish for active treatment, and if it seems that dying will be prolonged, then he would like euthanasia.

\section{SUMMARY}

These hypothetical but realistic cases illustrate the situations of youth who are grievously and irremediably ill, and suffering intolerably. It is important to detail such cases because they are generally unknown, having not been brought to public attention through litigation. As stated, Canada is likely to see less than ten cases of assisted dying requests from youth per year, but the suffering of such youth and the certainty that they will never recover from their serious illness instantiate the argument for the practice of assisted dying for mature minors.

\section{MATURe Minors ANd CARTER}

Youth such as Liam, Emily, and Himmat were not contemplated by the Carter decision because that case did not concern plaintiffs below the age of majority. Bill C-14 requires persons to be 18 years of age or older to access assistance in dying. ${ }^{54}$ Yet, some stakeholders and experts argue that mature minors and other subsets of the population are, or ought to be, eligible for assisted death. ${ }^{55}$ The government's commitment to study the issue ${ }^{56}$ is, as stated, codified in law. ${ }^{57}$

Even though the Supreme Court of Canada did not explicitly consider mature minors in Carter, the Supreme Court emphasized that one should not assume that the Supreme Court disapproves of extending the decision beyond the circumstances presented to it. The Supreme Court stated that its judgment "is intended to respond to the factual circumstances [of the] Questions," Toronto Sun (26 February 2016), online: <www.torontosun.com/2016/02/26/notion-ofmature-minors-being-able-to-end-their-lives-raises-thorny-questions $>$.

Government of Canada, News Release, "Government Introduces Legislation to Provide Medical Assistance in Dying" (14 April 2016), online: <news.gc.ca/web/article-en.do?nid=1051809>; House of Commons Debates, 42nd Parl, 1st Sess, Vol 148, No 39 (14 April 2016) at 1210 (Mr Andrew Scheer). Bill C-14, supra note 4, s 9.1. 
case" and that it made "no pronouncement on other situations where physician-assisted dying may be sought." ${ }^{58}$ In other words, the Supreme Court was not ruling out mature minors.

Indeed, the Supreme Court accepted several findings of fact made by the trial judge that support the eligibility of mature minors for assisted dying. The trial judge recognized that physicians must frequently assess the capacity of their patients to understand the discussion regarding their health conditions, and that "it was feasible for properly qualified and experienced physicians to reliably assess patient competence and voluntariness, and that coercion, undue influence, and ambivalence could all be reliably assessed as part of that process ... [and] that it would be possible for physicians to apply the informed consent standard to patients who seek assistance in dying." ${ }^{59}$ This experience and skill would be applied in determining the capacity of minor patients.

The trial judge was asked to contemplate the risk of lifting the prohibition against assisted dying on vulnerable populations, specifically the elderly and disabled, but which could also include minors. The trial judge concluded, and the Supreme Court accepted the fact, that

[a]s to the risk to vulnerable populations (such as the elderly and disabled) ... there was no evidence from permissive jurisdictions that people with disabilities are at heightened risk of accessing physician-assisted dying.... [And] there was no evidence of inordinate impact on socially vulnerable populations in the permissive jurisdictions, and that in some cases palliative care actually improved post-legalization. ${ }^{60}$

In other words, concerns regarding assisted dying for minors could be addressed by using the language offered in Carter when it considered other vulnerable groups.

\section{Mature Minors and Consent to Health Care in Canada}

\section{A. OVerview}

Canadian law forbids individuals under the age of majority from participating in many activities that are lawful for adults, such as drinking alcohol and gambling. ${ }^{61}$ But in the field of health care, a sharp demarcation by age alone regarding consent to medical treatment does not exist. Instead, the unique circumstances and characteristics of individuals play an important role in determining who should decide what is in a youth's best interest.

Mature minors are people under the age of majority who can understand and appreciate the consequences of accepting or refusing medical treatment. ${ }^{62}$ The law of mature minors developed in the context of reproduction; the cases addressed when the authority of parents as surrogate decision makers for children gives way to the authority of the developing

Carter, supra note 1 at para 127.

Ibid at para 106.

Ibid at para 107.

See e.g. Gaming Control Act, SO 1992, c 24, s 2(1).

Alan Meisel, Loren H Roth \& Charles W Lidz, "Toward a Model of the Legal Doctrine of Informed Consent" (1977) 134:3 American J Psychiatry 285; C et al v Wren, 35 DLR (4th) 419 [Wren]; Juliet Guichon \& Ian Mitchell, "Medical Emergencies in Children of Orthodox Jehovah's Witness Families: Three Recent Legal Cases, Ethical Issues and Proposals for Management” (2006) 11:10 Paediatric Child Health 655 . 
adolescent to make health care decisions for him or herself..$^{63}$ In all jurisdictions in Canada, mature minors have the right to consent to receive or to refuse medical treatment, irrespective of the wishes of others, provided they are competent ${ }^{64}$ have adequate information,${ }^{65}$ and are acting voluntarily ${ }^{66} \mathrm{Hence}$, even though Bill C-14 excludes mature minors, the question will arise as to whether mature minors, by operation of common law, are legally entitled to assisted dying procedures which the Carter decision determined to be health services.

The notion that minors can be sufficiently mature to make their own health care decisions has been codified by statute in six jurisdictions (British Columbia, Ontario, Quebec, New Brunswick, Prince Edward Island, and the Yukon). In Alberta, Saskatchewan, Manitoba, Nova Scotia, Newfoundland and Labrador, the Northwest Territories, and Nunavut, there is no legislative framework respecting informed consent by mature minors for medical treatment; in those jurisdictions, the common law governs. The common law mature minor doctrine holds that the ability to consent to medical treatment depends on one's capacity, which is related to, but not determined by, age. In both statutory law and common law, the principles of promoting autonomy and beneficence are express or implied.

\section{B. STATUTORY LAW}

The six Canadian jurisdictions that have statutory law allowing minors to make their own health care decisions approach the issue differently, with half specifying an age requirement, and the remainder basing the decision on capacity to understand the treatment and consequences.

In British Columbia, a person under the age of 19 (the age of majority ${ }^{67}$ ) may, under certain conditions, consent to health care. "Health care" is anything that is done for a healthrelated purpose, including but not limited to therapeutic, preventative, and palliative care. The conditions are that the health care provider must

a) explain to the minor person and be satisfied that they understand the nature, consequences, and the reasonably foreseeable benefits and risks of the health care, and

b) make reasonable efforts to determine and conclude that the health care is in the minor person's best interests. ${ }^{68}$

It is evident that this British Columbia statute aims to promote the minor's autonomy and beneficence.

See the United Kingdom House of Lords decision concerning contraception in Gillick $v$ West Norfolk and Wisbech Area Health Authority, [1986] 1 AC 112. See also the Alberta Court of Appeal decision concerning abortion, Wren, ibid.

64 B (R) v Children's Aid Society of Metropolitan Toronto, [1995] 1 SCR 315 [Children's Aid Society] Malette v Shulman (1990), 72 OR 2d 417 (CA); AC v Manitoba, supra note 6 at para 144; Rodriguez, supra note 10. Halushka v University of Saskatchewan et al (1965), 53 DLR (2d) 436 (Sask CA); Reibl v Hughes, [1980] 2 SCR 880.

Dueck (Re) (1999), 171 DLR (4th) 761 (Sask QB).

Age of Majority Act, RSBC 1996, c 7, s 1.

Infants Act, RSBC 1996, c 223, s 17. 
In Quebec, persons aged 14 years or older may independently consent to medical care or treatment, though if they are required to stay in a health or social services establishment (such as a hospital), then the minor's parents must be notified. ${ }^{69}$ If the proposed treatment is "not required by the state of his health" and it entails serous risk to the minor's health, then the parent or substitute decision-maker must consent. ${ }^{70}$ This statute expressly aims to promote both autonomy and beneficence.

New Brunswick's Medical Consent of Minors Act is the most permissive health care consent statute in Canada. Minors of at least 16 years of age may consent to medical treatment in the same manner as adults. ${ }^{71} \mathrm{~A}$ minor under the age of 16 years may provide effective consent to medical treatment if, in the opinion of a legally qualified medical practitioner, that person is capable of understanding the nature and consequences of the medical treatment, and the medical treatment being considered is in the best interests of both the minor person, and the minor person's continued health and well-being. ${ }^{72}$ The legislative aim is to promote autonomy and beneficence.

Ontario's Health Care Consent Act, 1996 codifies the common law with respect to mature minor consent to treatment. ${ }^{73}$ The HCCA provides that a person is presumed to have capacity with respect, inter alia, to treatment if that person is able to understand the information relevant to making a decision about the treatment, and able to appreciate the reasonably foreseeable consequences of a decision or a lack of decision. ${ }^{74}$ The HCCA does not identify a specific age that a person must have attained to make this decision. Health care practitioners must take reasonable steps to ensure that the person is capable of making a decision with respect to the specifically proposed treatment and that the person has consented to the proposed treatment. ${ }^{75}$

Similarly, Prince Edward Island has effectively codified the common law. Provincial law states that "[e]very person is presumed to be capable of (a) giving or refusing consent to treatment; and (b) making a health care directive, until the contrary is demonstrated." Health care practitioners effectively assess competence to consent on the basis of whether the patient can understand the information that is relevant to making a treatment decision, that the information applies to his or her particular situation, that the patient has the right to make a decision, and that the patient appreciates the reasonably foreseeable consequences of a decision or lack of a decision. ${ }^{77}$

Under Yukon law, persons of any age may consent to their own health care as long as they are capable of understanding and appreciating the consequences of that decision. ${ }^{78}$ When assessing competence, the health care provider must determine whether the patient

Civil Code of Québec, CQLR c C-1991, arts 11-25.

Ibid, art 17.

Medical Consent of Minors Act, SNB 1976, c M-6.1, s 2.

Ibid, ss 2, 3(1).

SO 1996, c 2, Schedule A [HCCA].

Ibid, ss 4(1), 4(2).

Ibid, s $10(1)$.

Consent to Treatment and Health Care Directives Act, RSPEI 1988, c C-17.2, s 3.

Ibid, s 7.

Care Consent Act, SY 2003, c 21, Schedule B, s 6(4). 
understands $^{79}$ the reasons for the proposed treatment, its nature, risks, benefits, and alternatives to treatment. ${ }^{80}$

Manitoba does not have a statute that addresses the validity of a minor's consent to medical treatment but does specify the age of 16 in a health-related statute. The Health Care Directives Act states that, "a person has capacity to make health care decisions if he or she is able to understand the information that is relevant to making a decision and able to appreciate the reasonably foreseeable consequences of a decision or lack of decision." $"$ "The statute presumes that people aged 16 and over have such capacity. ${ }^{82}$

\section{Common Law Mature Minor Doctrine}

Neither Alberta, Saskatchewan, Manitoba, Nova Scotia, Newfoundland, Northwest Territories, nor Nunavut has statutes that specifically address consent by minors to medical treatment. In these seven jurisdictions, the common law applies. The distinguishing feature of the common law mature minor doctrine is that once a child is determined by a medical practitioner to be sufficiently mature, then he or she alone decides whether to accept or refuse the proposed treatment. "At common law, when a minor is mature, no parental consent is required." 83

The mature minor doctrine resolves disputes regarding who, as between the parent and the developing child, may make the health care decision. ${ }^{84}$

\section{Mature Minors and Child Protection Related to Health Care in Canada}

A different legal situation arises when the issue is that a child needs protection because the child's parents are unable or unwilling to provide the child necessary medical treatment. Such a matter comes to the court as a matter of child protection law and the child's very life is usually at stake. ${ }^{85}$ The legal test in these circumstances is what is the best interest of the child, and the minor's wishes regarding his or her medical treatment is only one factor that will be considered.

\section{A. A.C. V. MANitoba: Child Protection}

Child protection was at issue in the Supreme Court of Canada's 2009 decision of A.C. v. Manitoba. ${ }^{86}$ The case concerned a fourteen year old girl, A.C., who suffered from Crohn's disease, and whose life was at risk from related internal gastrointestinal bleeding. A.C. refused a blood transfusion and had signed a declaration to that effect. Her parents did not

Ibid, s 6 .

Ibid, s 5(e).

CCSM 1992, c H27, s 2.

Ibid, s 4(2).

Walker (Litigation Guardian of) v Region 2 Hospital Corp (1994), 116 DLR (4th) 477 at 487 (NBCA).

See also Van Mol (Guardian ad Litem of) v Ashmore, 1999 BCCA 6, 168 DLR (4th) 637.

AC $v$ Manitoba, supra note 6 at para 86.

Ibid at para 86.

Ibid. 
give their consent to blood transfusion on her behalf. The Director of Child and Family Services obtained a treatment order under Manitoba's The Child and Family Services Act ${ }^{87}$ to compel A.C. to receive blood to preserve her life. The transfusion was successful and A.C. was discharged from hospital. The appeal challenged the constitutionality of the relevant provisions of the Manitoba Act, through which the Court had standing to authorize treatment that it considered to be in the child's best interests. The Supreme Court of Canada determined that the relevant sections of the Manitoba Act were constitutional when the interpretation of the best interests of the child sufficiently respects his or her capacity for mature, independent judgment in a particular medical decision-making context. ${ }^{88}$

In these child protection cases, the doctrine of parens patriae applies, rather than the mature minor doctrine. Parens patriae literally means "parent of the nation" and connotes the principle that the state is the legal protector of citizens who are unable to protect themselves, especially children. As the Supreme Court in an earlier case stated:

The protection of a child's right to life and to health, when it becomes necessary to do so, is a basic tenet of our legal system, and legislation to that end accords with the principles of fundamental justice, so long, of course, as it also meets the requirements of fair procedure. ${ }^{89}$

When exercising its parens patriae jurisdiction, the court must focus on the minor's best interests.

In considering the best interests of the child under the parens patria jurisdiction, the majority in A.C. v. Manitoba recognized that the minor had two important interests: exercising autonomy and receiving beneficent care that would preserve her life. The Supreme Court held that both interests must be considered together, without one being given a priority over the other, and that a court is more likely to regard a teen as sufficiently autonomous to make her own decisions if the teen chooses a treatment option that promotes the teen's health interests especially when the teen's life is at stake. In considering the minor's wishes as a part of the best interests analysis, a court must recognize that as the minor's degree of maturity increases, a minor's wishes will become increasingly co-extensive with his or her best interests.

To determine what is in a minor's best interests, a court must engage in an assessment that accounts for the particular young person's circumstances, the nature of the treatment decision, and the potential severity of the consequences. ${ }^{90}$ Although many adolescents may have the ability to make complex decisions, they will not always have the requisite maturity to make autonomous decisions about their medical care. ${ }^{91}$ The "best interests" standard must be interpreted in a way that reflects and addresses an adolescent's evolving capacities for autonomous decision-making. ${ }^{92}$ As a minor gains maturity, his or her views become more determinative of what his or her best interests are. ${ }^{93}$

CCSM c C80 [Manitoba Act].

AC v Manitoba, supra note 6 at paras 3, 21.

Children's Aid Society, supra note 64 at 374.

AC $v$ Manitoba, supra note 6 at para 9.

Ibid at paras $73-74$.

Ibid at para 88 .

Ibid at paras 22, 88 . 
In effect, the Supreme Court recognizes that there is a point where the minor's interest in autonomy and beneficence coincide. Justice Abella wrote:

It is not only an option for the court to treat the child's views as an increasingly determinative factor as his or her maturity increases, it is, by definition, in a child's best interests to respect and promote his or her autonomy to the extent that his or her maturity dictates. ${ }^{94}$

The Supreme Court affirmed that defining and identifying maturity are difficult tasks, but concluded that "the right of mature adolescents not to be unfairly deprived of their medical decision-making autonomy means that the assessment must be undertaken with respect and rigour" 95 and that minors "should be permitted to attempt to demonstrate that their views about a particular medical treatment decision reflect a sufficient degree of independence of thought and maturity" ${ }^{\prime 96}$ that the decision is respected. If a minor demonstrates this level of maturity, then the minor's wishes and views ought to be respected. ${ }^{97}$

In A.C. v. Manitoba, the majority contemplated that a minor's decision that would lead to his or her death could be respected by a court, but only after significant evaluation:

In those most serious of cases, where a refusal of treatment carries a significant risk of death or permanent physical or mental impairment, a careful and comprehensive evaluation of the maturity of the adolescent will necessarily have to be undertaken to determine whether his or her decision is a genuinely independent one, reflecting a real understanding and appreciation of the decision and its potential consequences. ${ }^{98}$

The Supreme Court of Canada's decision in A.C. v. Manitoba affirms previous case law. Prior to the decision, there were at least three cases, Director of Child Welfare (Alta.) $v$. H.(B.), ${ }^{99}$ U. (C.) (Next friend of) v. Alberta (Director of Child Welfare), ${ }^{100}$ and B. (S.J.) (Litigation Guardian of) v. British Columbia (Director of Child, Family \& Community Service), ${ }^{101}$ in which the courts found both that the child was a mature minor and that child welfare law could be used to override the child's decision. Understood as "if the minor is mature then the minor decides," the mature minor doctrine does not apply in child protection proceedings. Indeed, the British Columbia Supreme Court held in B (SJ) that

\footnotetext{
the Courts have repeatedly held that the legislature has the power to protect the life of a child who is endangered by his or her own refusal to accept necessary medical treatment, which power is not in any way constrained by the common law limits placed upon the parens patriae powers of a court of inherent jurisdiction. $^{102}$
}

In all three cases, physicians had testified that the proposed medical treatment (blood transfusion) was either necessary to preserve the child's life or necessary as an adjunct to

Ibid at para 88 .

Ibid at para 96.

Ibid at para 87.

Ibid at paras 87, 104.

Ibid at para 95.

2002 ABQB 371, 302 AR 201.

2003 ABCA 66, 223 DLR (4th) 662.

2005 BCSC 573, 42 BCLR (4th) 321 [B (SJ)].

Ibid at para 70 . 
treatment that had a strong chance of curing the child of cancer. In all three cases, the courts held that the minor would not be permitted to make a life-ending decision. The British Columbia Supreme Court held that the mature minor doctrine applies only against the parent or other surrogate decision-maker and does not oust the parens patriae jurisdiction of the state.

While accepting that a mature minor can provide an informed consent which cannot be overruled by the parent, the Courts determined the rule was overridden by the provisions of the [child welfare] Act regarding any minor for whom protection proceedings had been initiated. ${ }^{103}$

The Supreme Court in A.C. v. Manitoba asserted that the state continues to hold parens patriae power, which it uses to protect minors:

\footnotetext{
In this very limited class of cases, it is the ineffability inherent in the concept of "maturity" that justifies the state's retaining an overarching power to determine whether allowing the child to exercise his or her autonomy in a given situation actually accords with his or her best interests. The degree of scrutiny will inevitably be most intense in cases where a treatment decision is likely to seriously endanger a child's life or health. ${ }^{104}$
}

In other words, it will be difficult to demonstrate that a life-ending decision is in a minor's best interest.

\section{B. SUMMARY}

Like the statutory and common law that grant minors power to make health care decisions when opposed by their parents, the parens patriae power exercised in child protection law is an expression of the law's determination to promote autonomy and beneficence. The Supreme Court decision in A.C. v. Manitoba is a guide to assessing how a minor's autonomy and beneficence interests would be promoted by the minor's health care decision, and to determining when the state will intervene to override the minor's expression of autonomy in the minor's best interest in life-threatening situations.

\section{MATURe Minor ACCESS To Assisted DYing: Legal, ETHICAL, AND POLICY IsSUeS}

\section{A. Legal Argument for Mature Minor Eligibility to ACCess Assisted Dying}

If youth seeking assisted dying are deemed to be requesting ordinary health care, then the mature minor doctrine applies. As stated above, ${ }^{105}$ statute and common law provide that people under the age of majority have the right to accept or to refuse medical treatment if they have capacity. The fact that Bill C-14 does not grant physicians an exemption from criminal liability for assisting a mature minor to die effectively renders a health service

\footnotetext{
$103 \quad$ Ibid at para 71.

$104 \quad$ AC v Manitoba, supra note 6 at para 86. 
accessible on the basis of age and not capacity. Insofar as assisted dying is a beneficent form of health care ${ }^{106}$ this outcome is contrary to existing provincial and territorial health law.

\section{CARTER DOES Not EXClUde MinORS EXPLICITLY}

The exclusion of minors from access to assisted dying is not dictated by Carter. The Supreme Court of Canada did not consider whether the mature minor rule applies to assisted dying when it effectively ruled that assisted dying is a health service; the Supreme Court did not consider the issue because no plaintiff was under the age of majority. Indeed the Supreme Court specifically stated that its silence on other issues was not meaningful. The Supreme Court wrote, "[t]he scope of this declaration is intended to respond to the factual circumstances in this case. We make no pronouncement on other situations where physicianassisted dying may be sought."107

An argument that the Carter decision could include or be consistent with mature minor access to assisted dying has been advanced by Professor Jocelyn Downie

First ... it doesn't violate Carter to include mature minors. Second, even if Carter only held the Criminal Code prohibitions to be invalid for individuals over the age of majority, Carter sets a floor and not a ceiling, and the issue of minors was not before the court. The third and most important point is that to exclude individuals on the basis of a specific age flies in the face of established health law, policy, practice, and the Charter. ${ }^{108}$

\section{The Alberta COURT OF ApPEAl Supports A BROAD INTERPRETATION OF CARTER}

The understanding that Carter grants eligibility for assisted dying to other types of plaintiffs' circumstances and medical conditions was affirmed by a court of appeal in EF. ${ }^{109}$ As stated above ${ }^{110}$ the Alberta Court of Appeal ruled unanimously that the Carter decision does not require a person to be at the end of life to receive assistance in dying. Moreover, the Court strongly denied arguments that would limit the right to access assisted dying:

\footnotetext{
Any attempt to read in or infer additional limitations to those expressly set out in paragraph 127 [which states the criteria for assisted dying] must respect the balance of competing values struck by the court — balancing the sanctity of life, broadly speaking, and society's interest in protecting the vulnerable, against the Charter rights of an individual to personal autonomy without state intervention, including autonomy over personal decisions regarding one's life and bodily integrity. Given the importance of the interests at stake, it is not permissible to conclude that certain people, whose circumstances meet the criteria set out in the Carter 2015 declaration and who are not expressly excluded from it, nevertheless
}

The minor would be required to meet the Carter criteria: be grievously and irremediably ill, and experiencing physical or psychological enduring suffering that is intolerable to the minor and that cannot be relieved under conditions that the minor considers acceptable.

Carter, supra note 1 at para 127.

Special Joint Committee on Physician-Assisted Dying, Evidence, 42nd Parl, 1st Sess, No 7 (28 January 2016) at 1850 (Professor Jocelyn Downie), online: <www.parl.gc.ca/HousePublications/Publication. asp $x$ ? Language $=\mathrm{e} \&$ Mode $=1 \&$ Parl $=42 \&$ Ses $=1 \&$ DocId $=8077830>$.

EF, supra note 40 .

See Part II, above. 
can be inferentially excluded. It is not appropriate, in our view, to revisit these issues, which were considered at length and decided by the Supreme Court in Carter 2015, at authorization hearings conducted under it. ${ }^{111}$

The Alberta Court of Appeal affirmed that the Supreme Court focused on autonomy and beneficence by drawing attention to the fact that the cruelty of unwanted, prolonged suffering was the basis of the Supreme Court's decision.

The interpretation urged on us by Canada is not sustainable having regard to the fundamental premise of Carter itself as expressed in its opening paragraph, and does not accord with the trial judgment, the breadth of the record at trial, and the recommended safeguards that were ultimately upheld by the Supreme Court of Canada. ${ }^{112}$

The Alberta Court of Appeal also held that the Supreme Court did not exclude people with psychiatric conditions. In essence, the Court of Appeal affirmed that courts should not exclude people based on categories (such as physical or mental illness). Rather, each decision should be based on individual circumstances, as physicians ordinarily make care decisions: the Supreme Court of Canada "accepted the trial judge's finding that it was feasible for properly qualified and experienced physicians to reliably assess patient competence and voluntariness, and that coercion, undue influence and ambivalence could all be reliably assessed as part of that process."

Although the Alberta Court of Appeal's decision addressed persons with psychiatric illnesses as a vulnerable population, the decision supports the notion that persons whose conditions do not resemble that of the plaintiffs considered by Supreme Court of Canada in Carter should not be excluded from accessing assisted dying on that basis alone. The Alberta Court of Appeal rejected the notion that the Supreme Court intended "to further limit the right, or to establish narrower or different criteria that conform to the specific facts of Ms. Taylor's case." 114 The Court of Appeal expressly stated that the Supreme Court left the door open to mature minor eligibility:

Rather, we read those sentences as clarifying that the criteria established in the declaration respond to the circumstances before the court. The court is noting that there may be other circumstances, not before the Court in Carter 2015, where a person who does not satisfy the Carter 2015 criteria, for example a mature minor, may seek a declaration of invalidity. The court is careful to state that it is not opining on the merits of applications that may be made in the future. ${ }^{115}$

Two of three government-funded panels recommended that assisted dying be available to eligible minors. ${ }^{116}$ The Territorial Working Group on Physician Assisted Dying (PTAG) ${ }^{117}$

EF, supra note 40 at para 40.

Ibid at para 41 .

Ibid at para 57.

Ibid at para 34.

Ibid.

Provincial-Territorial Expert Advisory Group on Physician-Assisted Dying, Final Report (30 November 2015) at 34, online: <www.health.gov.on.ca/en/news/bulletin/2015/docs/eagreport_20151214_en.pdf> [Provincial-Territorial Expert Report]; Canada, Special Joint Committee on Physician Assisted Dying, Report of the Special Joint Committee on Physician-Assisted Dying (Ottawa: Senate and House of Commons, 25 February 2016), online: <www.parl.gc.ca/content/hoc/Committee/421/PDAM/Reports/ 
noted that the Carter decision does not define the term "adult" and argues that an arbitrary age limit does not provide a valid safeguard. The PTAG suggested that willing physicians should consider each specific request in context to determine whether the patient is competent to make a decision about assisted dying. The Special Joint Committee recommended that eligibility for assisted dying be extended to include competent, mature minors. ${ }^{118}$

\section{Denial of Health Service Based on Age Alone IS INCONSISTENT WITH INTERNATIONAL LEGAL OBLIGATIONS}

If assisted dying is considered a health service, then international law obligations that require Canada to respect the health care decisions of mature minors support the view that access to assisted dying should not be based on age but on capacity. Canada is a signatory to the United Nations' Convention on the Rights of the Child,${ }^{119}$ which requires state parties to

assure to the child who is capable of forming his or her own views the right to express those views freely in all matters affecting the child, the views of the child being given due weight in accordance with the age and maturity of the child. ${ }^{120}$

A minor's request for assisted dying is a matter "affecting the child." The UNCRC also accepts that children develop into maturity and therefore requires state parties to respect the "evolving capacities of the child"121 in the degree to which parents aid their children's decision-making. These two sections of the UNCRC do not support an arbitrary age limit, but rather capacity-based criteria for eligibility to assisted dying.

The argument that mature minors should have capacity-based access to assisted dying was advanced by the Canadian Coalition on the Rights of the Child advocacy group. The Coalition claimed that

While the state has a legitimate interest in protecting those who are vulnerable, choosing an arbitrary age upon which to grant the right to assistance in ending the intolerable suffering of a prolonged dying, would not likely stand up to scrutiny under the Charter or the UN Convention on the Rights of the Child. $^{122}$

RP8120006/pdamrp01/pdamrp01-e.pdf $>$ [Special Joint Committee Report]. See Canada, External Panel on Options for a Legislative Response to Carter v. Canada: Consultations on Physician-Assisted Dying: Summary of Results and Key Findings: Final Report (Ottawa: 15 December 2015).

Provincial-Territorial Expert Report, ibid at 34.

Special Joint Committee Report, supra note 116 at 21.

20 November 1989, 3 UNTS 1577 (entered into force 2 September 1990) [UNCRC].

Ibid, art 12.1 .

Ibid, art 14.2 .

Canadian Coalition for the Rights of Children, "Submission of the Canadian Coalition on the Rights of the Child to the Special Joint Committee on Physician-Assisted Dying" (12 February 2016), online: $<$ rightsofchildren.ca/wp-content/uploads/2016/04/CCRC-Submission-on-Physician-AssistedDeath.pdf>. 
Arguably, mature minors are eligible for assisted dying as access to a lawful health service, provided assistance in dying in the particular case promotes both autonomy and beneficence.

\section{B. Legal Argument for Mature Minor Eligibility to ACCess Assisted Dying Based on Child Protection LaW}

Assuming, in the alternative, that assisted dying is not prima facie considered to be a beneficial health service, then considerations of child protection arise. Under this body of law, as articulated by the Supreme Court in A.C. v. Manitoba, a choice by a minor to access assisted dying requires significant scrutiny because the consequences of giving effect to the child's expression of autonomy are that the child will die. The question then is, as ever, whether that choice is a true expression of autonomy and whether it would be beneficent, that is, in the minor's best interests.

If the minor, the parents and the medical team are in agreement that the choice to die with assistance is in the minor's best interests, then arguably the child is not in need of intervention as contemplated by child welfare statutes because concerns for autonomy and beneficence have been addressed by people closest to the situation, including the health care professionals.

Nevertheless, child protection services might be notified by another party claiming that a youth seeks assistance in dying. In assessing whether the minor's choice ought to be respected, the child protection officials would be obligated to employ the analysis set forth in the A.C. v. Manitoba decision. There, Justice Abella provided a non-exhaustive list of criteria to consider when weighing the child's best interests to help determine whether the minor's wish reflects true, stable, and independent choices:

What is the nature, purpose and utility of the recommended medical treatment? What are the risks and benefits?

Does the adolescent demonstrate the intellectual capacity and sophistication to understand the information relevant to making the decision and to appreciate the potential consequences?

Is there reason to believe that the adolescent's views are stable and a true reflection of his or her core values and beliefs?

What is the potential impact of the adolescent's lifestyle, family relationships and broader social affiliations on his or her ability to exercise independent judgment?

Are there any existing emotional or psychiatric vulnerabilities?

Does the adolescent's illness or condition have an impact on his or her decision-making ability?

Is there any relevant information from adults who know the adolescent, like teachers or doctors? ${ }^{123}$ 
If child protection officials were involved, then the director of child welfare might refer the decision to the court. A court intervention might be heard on the basis of an emergency application. The minor might die in the interim in a more painful way than he or she wanted. A court intervention might require the youth and parents to seek legal counsel, incurring costs on the family. The physicians would be called upon to create documents providing evidence of the medical situation, and legal costs would be incurred by their insurers and perhaps also by the hospital.

\section{Ethical Argument for Mature Minor Eligibility to ACCeSS Assisted Dying}

\section{AVOIDANCE OF SUFFERING}

The ethical argument that mature minors are eligible for assisted dying is based on the view that human dignity should be respected, by giving effect to the principles of autonomy, beneficence, and equality.

As the Supreme Court of Canada made clear, it is inconsistent with the principle of autonomy to require people who are grievously and irremediably ill to be condemned to severe and intolerable suffering. The Supreme Court recognized that assisted dying can be beneficent when it held that it is cruel to force such people to choose between taking their own life prematurely, often by violent or dangerous means, or suffering until they die from natural causes. The cruelty that the Supreme Court acknowledged is the same for all people, regardless of their age.

\section{PROMOTING EQUALITY}

The inequality is evident in considering a mature minor's existing eligibility for withdrawal of life sustaining treatment. A person under the age of 18 might be dependent on life-sustaining treatment, but suffering intolerably. He or she may therefore request that the intervention be withdrawn. At that point, physicians would conduct an assessment of capacity. If physicians agreed that the individual is a mature minor and consents, then the patient's decision to withdraw the intervention, with death as the most likely outcome, would be given effect by the physician in accordance with current medical practice, and without the need for approval of an administrative office outside the hospital. ${ }^{124}$ In practice, in almost every case where life-sustaining therapy is withheld or withdrawn from a mature minor, physicians also seek consent from the parents. By contrast, if the same mature minor is enduring intolerable suffering, and yet is not dependent on life sustaining treatment, even if his or her parents agree with the course of action, Bill C-14 forbids access to assisted dying.

A criminal prohibition on assisted dying for mature minors implies that intolerable suffering, experienced by one youth (receiving life-sustaining treatment), can be relieved within the law, but forbidden for another teen with equal suffering. The difference between the two cases is the dependence on life-sustaining treatment, not the degree of suffering, or

124 Christopher Doig \& Ellen Burgess, "Withholding Life-Sustaining Treatment: Are Adolescents Competent to Make These Decisions?" (2000) 162:11 CMAJ 1585 
the maturity of the minor. This difference is difficult to justify and is unethical from the perspective of alleviating the suffering of the patient.

\section{No Ethical Distinction Between \\ PASSIVE AND ACTIVE MEANS OF ENDING LIFE}

The argument that there is no sharp distinction between withdrawing life sustaining treatment and actively assisting dying, is one of the fundamental reasons for allowing assisted dying. As two commentators wrote concerning a United Kingdom case:

\footnotetext{
What is deemed to be morally and legally important here is not the emotionally appealing distinction between omission and commission but the justifiability or otherwise of the clinical outcome. Indeed, the distinction between omission and commission may be of little value in some healthcare settings. When doctors turn off ventilators, foreseeing that death will result, it makes little sense to say that they do so passively. $^{125}$
}

The ethical nature of the distinction between actions that lead directly or indirectly to death was examined by the judge in Carter Trial, who quoted evidence that 90 percent of deaths in Canadian critical care units involve "withdrawal of some form of life-support."126 The judgment examined direct evidence and statements on cross-examination from plaintiff and defendant witnesses, and concluded:

\footnotetext{
There cannot be an ethical bright line between the three conventionally accepted measures and these further ones, since they all serve exactly the same core values. If these widely accepted measures are justified, under conditions of patient informed choice and patient best interest, then so is assisted death. $^{127}$
}

Some might argue that requesting assisted dying is relevantly different from withholding medical treatment because forcing someone to undergo unwanted medical treatment is an extreme violation of individual integrity, whereas denying someone the right to seek assistance in dying does not force that person to have an invasive and unwanted treatment. But, as the cases of Liam and Emily demonstrate, some people who are grievously and irremediably ill who are not aided to die will either be required to receive the unwanted medical treatment of tracheostomy or assisted ventilation, or they will die from the very difficult process of asphyxiation. To quote the Supreme Court of Canada, the "choice is cruel." 128

\section{ReleVAnCE OF NeUroimaging Data}

It is important to note that recent neuroimaging studies present evidence that adults and adolescents are relevantly dissimilar regarding decision-making. Magnetic resonance imaging (MRI) studies of the adolescent brain demonstrate that complete maturation and

Len Doyal \& Lesley Doyal, "Why Active Euthanasia and Physician Assisted Suicide Should be Legalised" (2001) 323 BMJ 1079 at 1079.

126 Supra note 26 at para 185.

$127 I$ Ibid at para 234 (quoting Professor Wayne Sumner, who served as an expert witness).

128 
myelination may not be complete until 25 years of age. ${ }^{129}$ The same report describes immaturity in all lobes, particularly the frontal lobe, an area central to, among other aspects, abstract reasoning, judgment, and strategizing. The cerebellum, which is important in "navigating complicated social situations" may be the last area of the brain to mature. Neurotransmitters, such as dopamine, are high in adolescents and may be important in the onset of addictions. Use of alcohol or marijuana is likely to damage the hippocampus and affect learning and ability to recall.

Similarly, another report also suggests that adolescents are not sufficiently mature to make important health care decisions:

[T] he adolescent's ability effectively and adequately to envisage the consequences of important decisions is limited by the turmoil of adolescence, immature emotional responses, and a relatively incomplete capacity to appreciate the consequences of choices that reach beyond the immediate future. Such psychological observations are further supported with neurophysiological imaging studies on the physical development of the adolescent brain that demonstrate the relative immaturity of the prefrontal cortex, the seat of executive function, as compared to the limbic system, the source of emotional and pleasureoriented short-term response. In emotionally charged circumstances, for example, the more mature limbic system dominates the less fully developed prefrontal cortex. ${ }^{130}$

These and similar arguments based on neuroimaging do not, however, demonstrate that mature minors ought never to be assisted to die. They do raise questions as to how best to promote the minor's autonomy and how to act in a beneficent manner.

\section{Policy CONSIDERATIONS}

\section{CONSIDERATIONS CONCERNING PARENTAL CONSENT}

Teens who request assisted dying are likely to have been involved with medical services for some years before they make a request for assisted dying. Their parents will probably have been intensely involved in the medical care of the minor because that is typically the case with parents of children with life threatening disorders, such as neuromuscular diseases or malignant disorders. It is entirely possible that parents might object to a minor's decision to die with assistance. It is important to respect this involvement, and the effects on parents should their child die by assisted dying without their consent or assent.

Accepting that access by youth to assisted dying can be an ethical response to enduring and intolerable suffering from grievous and irremediable illness, it is important to consider, as a practical matter, the role of parents. Given the irreversibility of granting the minor's choice and the effect on the parents, physicians would, as a practical matter, find it difficult to disregard the parents' objections. 
Both the Netherlands and Belgium have addressed this practical issue by requiring parental consent, at least if the minor is under 16. In the Netherlands, since 2002, physicians may grant requests for assisted dying (both euthanasia or physician-assisted suicide) from minors aged 12 to 16 years if parents agree, and from minors aged 16 or 17 years if the parents are informed. If the child is younger than 12 years, neither euthanasia nor physicianassisted suicide is permitted. ${ }^{131}$

In Belgium, the minor must be near death and have a terminal and incurable illness, suffering constant and unbearable physical ${ }^{132}$ pain, and the parents and professionals who are involved in the patient's care must agree to the choice. ${ }^{133}$ The family must be offered psychological care if desired after the act of euthanasia. ${ }^{134}$

Notwithstanding the Carter decision which makes assisted dying a health service and the mature minor doctrine which makes parental consent unnecessary where minors are sufficiently mature to consent to a health service, Canadian policy-makers ought to consider following the example of the Netherlands and Belgium to ensure consent of both the adolescent and the parents before an assisted death might occur, given the life ending consequences of the decision.

\section{CONSIDERATIONS ABOUT Political CAPITAL AND ACTUAL BENEFIT}

A second policy matter is the argument that tremendous political capital would need to be expended on making the practice explicitly lawful when few minors would access assisted dying. This is an argument which has received an answer in Belgium. When no minor had yet accessed Belgian assisted dying, Dr. Wim Distelmans said, "In theory, it is worth it even if you only help just one young person." 135 Likewise, Belgian politician, Jean-Jacques De Gucht, then evaluated the efforts to make the practice lawful: "Of course it was worth it. I am glad that young people have not yet had to use it, which is good. I hope there will be as few people as possible in the future to make these difficult choices. In euthanasia, it is not the numbers, but the option, and the peace that follows." 136

131 In certain limited cases, euthanasia of infants is permitted. See Eduard Verhagen \& Pieter JJ Sauer, “The Groningen Protocol - Euthanasia in Severely Ill Newborns" (2005) 352:10 New Eng J Med 959.

132 28 MAI 2002: Loi relative à l'euthanasie, art 3(1), online: $<$ www.ejustice.just.fgov.be/cgi_loi/change lg.pl?language $=$ fr $\&$ la $=$ F\&cn $=2002052837 \&$ table name $=$ loi $>$. See also partial English translation of this document, B.S. 22 June 2002, as amended by the Law of 13 February 2014, s 3(1), Dalhousie University Law Faculty, End of Life Project, "Recent Belgian Law Reform," online: <eol.law.dal.ca/wpcontent/uploads/2015/06/Law-of-28-May-2002-on-Euthanasia-as-amended-by-the-Law-of-13-February2014.pdf $>$.

Ibid, art 2(7).

Ibid, art 4.

Dr. Wim Distelmans is Chair of the Belgian Federal Control and Evaluation Commission (FCEC) regarding assisted dying. Ibid: "In theorie is het de moeite, zelfs als je er ooit maar één jongere mee zou helpen."

136 Ibid: "Natuurlijk is het de moeite geweest. Ik ben blij dat jongeren er tot nog toe geen gebruik van hebben moeten maken. Dat is goed. Ik hoop dat er in de toekomst ook zo weinig mogelijk minderjarigen voor die moeilijke keuze worden gesteld. Het gaat bij euthanasie niet om de aantallen, maar om de keuzemogelijkheid, en de gemoedsrust die daarop volgt." 


\section{CONCLUSION}

The Supreme Court of Canada, by its unanimous decision, has made assisted dying a health service for a small group of people in Canada. Parliament has responded by making assisted dying lawful for a narrower group of persons. While the Supreme Court did not consider minors, Parliament specifically excluded them from having access to assisted dying.

Nevertheless, it is likely that some minors will request assisted dying because they are grievously and irremediably ill, experiencing enduring physical or psychological suffering that is intolerable, and that cannot be relieved under conditions that the minor considers acceptable. ${ }^{137}$ Under statutory and common law in Canada, mature minors may consent and refuse to consent to health services, including withdrawal of life-sustaining measures. Insofar as assisted dying is now a lawful health service, the mature minor doctrine holds that mature minors ought to have access to assisted dying provided that they are competent, wellinformed, and acting voluntarily. If, in the alternative, assisted dying is not considered a health service but a matter that raises issues of child protection, then an assessment must be conducted based on the decision in A.C. v. Manitoba to determine whether assisted dying would promote the minor's interests in autonomy and beneficence.

Accepting that youth who seek assistance in dying will tend to be medically complex children whose parents have been intensely involved in the minor's health care and that death is irreversible, it would be prudent for a regime that permits assisted dying to proceed only on the basis that an otherwise eligible minor and his or her parents agree. 